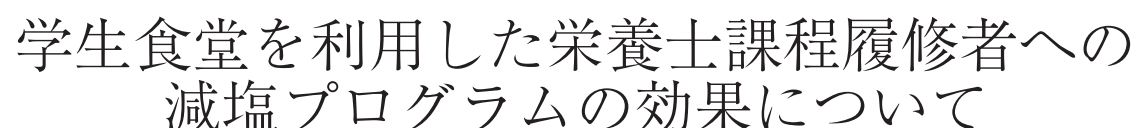

下山春香* · 中島里美* · 宮地博子* · 北山育子* · 木田和幸**

(*東北女子短期大学, **弘前大学大学院保健学研究科)

(平成29年 9 月11日受付，平成30年 9 月21日受理）

\title{
Effect of a salt reduction program among student nutritionists using a student cafeteria
}

\author{
Haruka Shimoyama *, Satomi Nakashima*, Hiroko Miyachi *, \\ Ikuko Kitayama*, Kazuyuki Kida**
}

*Tohoku Woman's Junior Collage, 25, Kamikawarake-cho Hirosaki-shi, Aomori, 036-8503

** Hirosaki University Graduate School of Health Sciences, 66-1, Hon-cho Hirosaki-shi, Aomori, 036-8564

*厂036-8503 青森県弘前市上瓦ヶ町25

**\%036-8564 青森県弘前市本町66-1

\begin{abstract}
This study aimed to assess the effect of a salt reduction program among junior college students with respect to their awareness of salt reduction and intake. Student nutritionists at T Junior College were included, and the study was implemented in individual and team units. Surveys were conducted in Terms I, II, and III considering scholastic levels. Food service management training was used to administer three tests: taste tests, dietary habit surveys, and salt intake surveys. The program comprised learning about salt reduction, devising reduced-salt menus and continuous intake, and creating leaflets. The analysis targets were 53 individuals and 5 teams with completed data. In the taste tests, salt intake levels selected as close to everyday salt flavors were significantly lower in Term II than in Term I $(p<0.05)$. In the salt intake surveys, the estimated salt intake was significantly lower in Term II than in Term I ( $p$ $<0.05)$. From Term II onward, because of continuous learning of nutrition and specialized knowledge during lectures and practice, congruence developed between subjects' taste of salt and their knowledge concerning appropriate salt levels. Thus, through this program, students developed the knowledge and taste of reduced salt and could devise salt-reduced meals.
\end{abstract}

\section{1. 序論}

日本人の食事摂取基準 $2015^{1)}$ によると,ナトリウム（食 塩相当量) の摂取目標量は男性 $8.0 \mathrm{~g} /$ 日, 女性 $7.0 \mathrm{~g} /$ 日に設定されている。一方, 厚生労働省の平成27年「国 民健康・栄養調査」の結果 ${ }^{2}$ によると成人の 1 日食塩摂 取量の平均值は総数で $10.0 \mathrm{~g} /$ 日, 男性 $11.0 \mathrm{~g} /$ 日, 女 性9. $2 \mathrm{~g} /$ 日である。10年間の推移をみると減少傾向に あるが，社会全体で取り組むべき減塩問題といわれるほ
ど未だ高い数值である。ナトリウムの過㮃な摂取が健康 の保持増進に影響を与えていること ${ }^{3-7)}$ は広く知られて 扮り, 日本高血圧学会では, 減塩目標值を $6 \mathrm{~g} /$ 日未満 と設定 ${ }^{8)}$ し, WHO が発表した塩分摂取の新ガイドライ ン ${ }^{9)} て ゙ は ， 1$ 日の摂取量をナトリウム $2,000 \mathrm{mg}$ (また は塩 $5 \mathrm{~g}$ ) と強く推奨している。

青森県の食塩摂取量は, 男性 $11.7 \mathrm{~g} /$ 日, 女性 $9.8 \mathrm{~g} /$ 日で全国の平均值を上回る状況 ${ }^{10)} に あ り ，$ 高血圧症をは じめとした種々の疾患の原因にもなりうる現状である。 
都道府県別平均寿命 ${ }^{11,12)}$ によると, 青森県の平均寿命は 男女ともに最下位であり，各年齢に扔ける平均余命もま た最下位で ${ }^{13)}$ ，食塩摂取量が要因の一つである高血圧者 の割合は，男女ともに40４9歳代で全国より高い。本研 究の対象者が所属する大学においても 7 割以上が県内出 身者であり，今後同様な状況に扔かれる可能性がある。 農林水産省の第 3 次食育推進基本計画の重点課題として, 若い世代を中心とした食育の推進や, 健康寿命の延伸 ${ }^{14}$ につながる食育の推進が挙げられており, 生活習慣病の 発症予防の一つとして減塩が勧められている。青森県の 健康状態の状況を踏まえ, 若い世代の健康づくり対策の 一つとして滅塩について学習することは，健康的な食生 活につながると考えられる。

本研究では, 栄養士課程の短期大学学生に対して減塩 プログラムを行うことにより，学生の減塩に対する意識 の変化や実際の食塩摂取量に与える影響を検証すること を目的とした。

\section{2. 方 法}

\section{（1）対象者および調査期間}

対象者は同意を得られた T女子短期大学の 2014 年入学 の栄養士課程履修学生78名である (以下対象者とする)。

調查期間は, 2014年10月～2016年 2 月に, 1 年後期 ( I 期)， 2 年前期 (II 期), 卒業時（III期）の 3 期に分けて 実施した（図 1)。

\section{（2）調査内容}

はじめに本研究の主な調查は, 学生食堂を使用する給 食管理実習を利用して実施した。給食管理実習とは，栄 養士課程履修学生が大量調理を学ぶ実習で, 連続した 5
日間の昼食時に 100 食以上を提供しているものである。 1 年後期 ( I 期)， 2 年前期（II期）の 2 回実施している。 班編成は， 1 班11名程度の 7 班編成であり 1 年次の 1 班 は 2 年次の 1 班のように対応している。実習で調理した 食事は, 学生食堂で提供して扮り, 対象者も該当する班 で全員喫食している。食堂の利用者は，食券を購入した 在学生㧍よび教職員である。献立構成は, 主食, 主菜, 副菜, 副菜 2 , 汁物の 5 品である。

\section{1 ）味覚テスト}

味覚テストは, 個人単位で I 〜 III 期ごとに各 1 回, 計 3 回実施した。試料には，味噌汁やすまし汁のだしの効 果や調味料による差異をさけるため食塩水を利用した。 試料の食塩濃度は，体液と同じ $0.9 \%$ を基調とした汁を 口に含んだときに快適さを感じるとされている ${ }^{15}$ ことか ら， $0.9 \%$ 前後を基準とし $0.5 \%, 0.7 \% ， 0.9 \% ， 1.1 \%$, $1.3 \%$ の 5 段階に調整した。手順として, 調査者が食塩 濃度の低いものから順にスポイトで対象者の舌上に滴下 し, 日常の塩味に近い濃度の番号を選んでもらい用紙に 記入させた。その値を真の值とした。次に, 対象者自身 が選んだ食塩水の予想濃度を記入させ予想值とした。た だし対象者には，食塩濃度は知らせていない。

\section{2 ）食習慣に関するアンケート}

個人単位で I 〜期ごとに実施した。質問内容は，日 頃の食習慣について，食習慣を意識したことがあるか， ある場合は気をつけている項目を選択させるなど，塩分 の摂り方についての設問を設定した。栄養士課程履修者 としての知識を問うものとして青森県の食塩摂取量を 知っているか, 知っている場合は摂取量 $(\mathrm{g} /$ 日) $）$ がど のくらいかなどの設問を設定した。

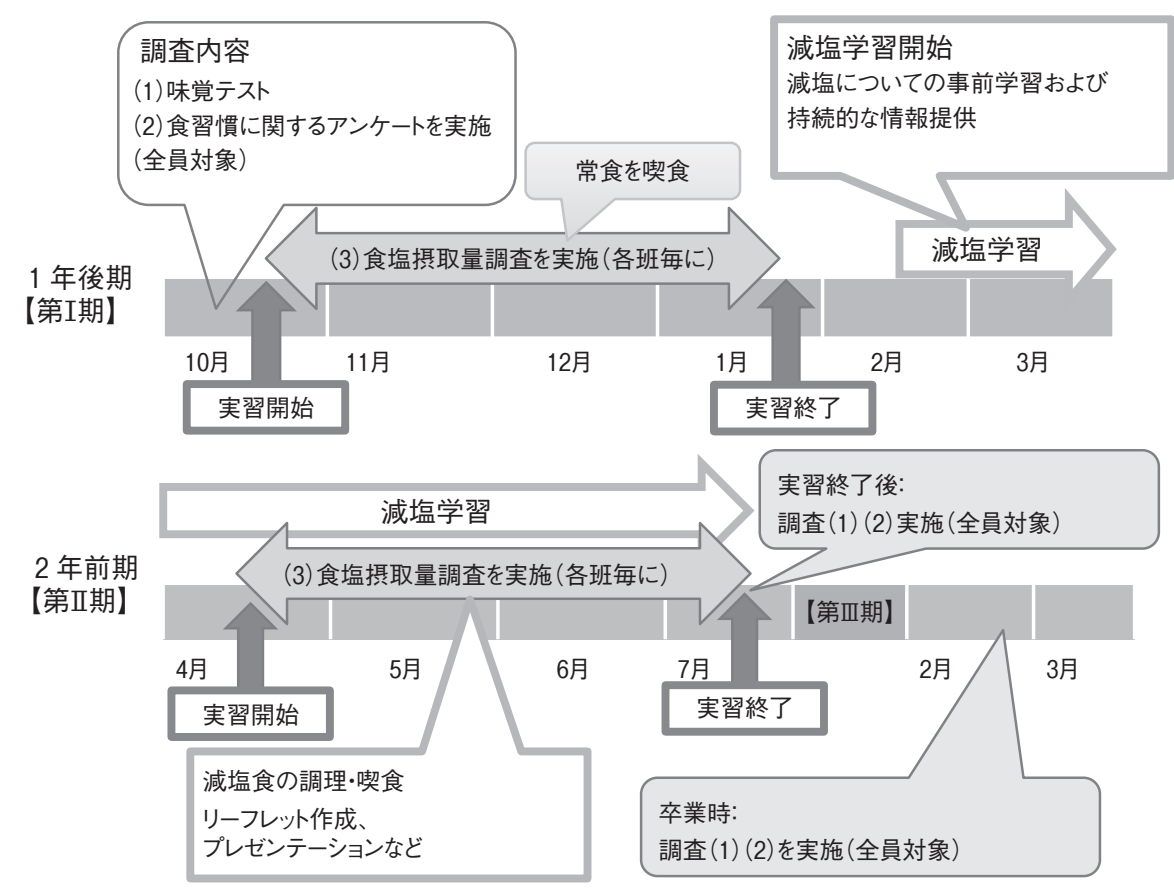

図 1 調查内容と実施時期 


\section{3）食塩摂取量調查}

食塩摂取量調査は，給食管理実習で調理した料理を利 用して，I期とII期に班単位で実施した。実際に摂取し た食塩量を推定するために，以下の 3 種類（1)～(3)）の 試料の食塩濃度を測定した。

(1) 提供された 1 食分の料理に含まれる食塩量の測定 (実測值)

(2) 食事中に使用した調味料中の食塩量の計量

(3) 食器や残菜に含まれる食塩量の測定

これらの測定法および測定值の妥当性を確認するため に，以下の予備実験を行った。

\section{【予備実験】}

試料は，大量調理により調理した食事の中から，無作 為に 5 食を抽出した。1 食ごとに食品重量を計量し, そ の重量と同量の蒸留水を加え, 3 分間 $\times 2$ 回ミキサーで 攪拌した ( 2 倍希䣋)。さらにその溶液から $10 \mathrm{~g}$ を採取し, 蒸留水を加えて 20 倍に希釈した。試料を各 4 回イオン メータ（Naイオンメータ：HORIBA 社製 LAQUAtwinB -722型式）で測定し, 変動係数を算出した（表 1 )。こ の結果を確認後，以下の 3 種類の調査を行った。

\section{【本調査】}

\section{(1) 提供された 1 食分の料理に含まれる食塩量の測定} (実測值)

試料は対象者が調理を行った100食前後の食事から無 作為に 2 食を抽出した。試料は，1 食ごとに重量を計量 後, 同量の蒸留水を加えてミキサーで攪拌し， 2 倍希釈 した。次に，2 倍希䣋した溶液の中から，10 $\mathrm{g} \times 3$ 個を 採取し, 蒸留水を $90 \mathrm{~g}$ 加えて20倍希釈した。1 食あた り 3 試料を作成した。各試料を 3 回イオンメータで測定 し平均值を算出した（以下実測值）（図 2 ）。その際使用 する献立は，あらかじめ五訂増補食品成分表 ${ }^{16)}$ を用いて 栄養計算し, 食塩量は約 $3.0 \mathrm{~g}$ に調整したものである（以 下献立值)。献立は， II 期の実習においても同一献立を 用いることから，料理に含まれる食塩量（実測值）はI 期のみ測定した。併せて, 献立值と実測值の食塩量の差 異についても調査した。また, 班ごとのばらつきを少な
くするために，調査実施日は実習の最終日（5日目）に 設定した。使用献立は，ご飯，みそ汁はわかめとねぎ， 主菜はフライ (肉または魚), 付け合せにキャベッの千 切り，ミニトマト，副菜はお浸しと炒め物という共通の 構成とした。

\section{(2) 食事中に使用した調味料（しょうゆ・ソース等） の食塩量の計量}

食事中に各自が使用した調味料は, 卓上調味料の重量 を喫食の前後で計量し，その差から摂取量を算出した。 I 期・II期で計量を行った。

\section{(3) 食器や残菜に含まれる食塩量の測定}

食器および残菜に含まれる食塩量をイオンメータでI 期・II期に測定した。食器に付着した調味料中の食塩量 を測定するため, 食器を蒸留水で洗い流して容器にため た。残食があった場合は残食を蒸留水ごとミキサーで覺 找して試料とした。

以上の 3 種類の調査の測定值および計量值から，実際 に摂取した食事の食塩量を推定した。

\section{（３）減塩プログラム（減塩学習）}

今回の調査では，学生食堂の利用で対象者全員に同等 の食事を利用した減塩プログラム（減塩学習）が行える ことを前提として以下の 3 項目を設定した。

(1) 減塩に関する事前学習課題と持続的な情報提供

(2) 減塩食の献立の工夫と継続攝取

(3) リーフレット作成とプレゼンテーション発表

\section{(1) 減塩に関する事前学習課題と持続的な情報提供}

I 期では減塩に関する情報提供を行わず，I 期終了時 から， II期開始前にかけて, 対象者に事前学習課題を課 した。対象者は，食塩の働きについてや，減塩する意味 と効果, ナトリウム表示から食塩相当量への換算方法, 調理の工夫と塩分を多く含む食品の利用法, 普段の食生 活の中で塩分を減らす工夫等について調べ学習し，レ ポート提出をした。課題提示の際, 著者らは情報提供と して, 減塩に関する書籍等の内容紹介を行った。また学

表 1 食塩摂取量調査の予備実験結果

\begin{tabular}{|c|c|c|c|c|c|c|}
\hline & 食事 1 & 食事 2 & 食事 3 & 食事 4 & 食事 5 & 変動係数（\%） \\
\hline 食事重量（g） & 603 & 614 & 608 & 610 & 608 & 0.65 \\
\hline $\begin{array}{l}\text { 水 }+ \text { 食事重量 }(\mathrm{g}) \\
(2 \text { 部希釈) }\end{array}$ & 1,206 & 1,228 & 1,216 & 1,220 & 1,216 & 0.65 \\
\hline 食塩量*（g） & 3. 39 & 3. 68 & 3. 47 & 3. 48 & 3.24 & 4. 62 \\
\hline \multicolumn{7}{|l|}{ 塩分測定值（g） } \\
\hline 1 回目 & 0.18 & 0.20 & 0.19 & 0.19 & 0.19 & \\
\hline 2 回目 & 0.19 & 0.20 & 0.19 & 0.19 & 0.17 & \\
\hline 3 回目 & 0.19 & 0.20 & 0.19 & 0.19 & 0.18 & \\
\hline 4 回目 & 0.19 & 0.20 & 0.19 & 0.19 & 0.18 & \\
\hline 変動係数（\%） & 2.67 & 0.00 & 0.00 & 0.00 & 2.81 & \\
\hline
\end{tabular}

* : 各試料 4 回の測定值の平均值 $\times$ (食事重量 + 水の量 $) / 100$ 


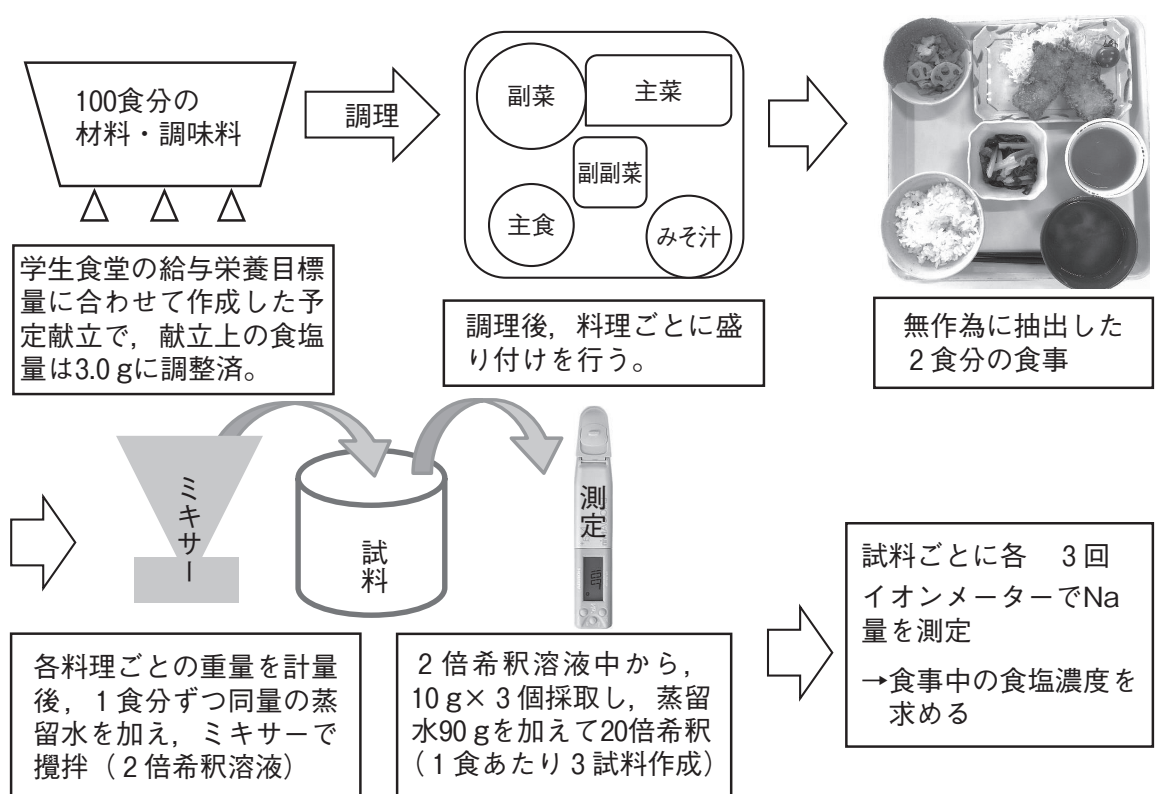

図 2 食塩摂取量調査（提供された 1 食分の料理に含まれる食塩濃度の測定）の流れ

生ホールには，ポスターや卓上メモの媒体を設置した。 これらは，都道府県別の平均寿命の分布や県民の健康状 態の現状，食事摂取基準の摂取目標量の表示，なぜ減塩 が必要なのか等の情報についてまとめたもので，普段か ら対象者が利用する学生ホールの揭示板や柱などを利用 したものである。それらを学習したうえで，国立循環器 病センターから講師を招いて，なぜ減塩が必要なのかな どセンターが取り組んでいる「かるしおプロジェクト」 について講演をいただいた。

\section{(2) 減塩食の献立の工夫と継続摂取}

減塩食の献立の工夫として, 実習で提供する献立は常 食（ 1 食の食塩約 $3.0 \mathrm{~g}$ ) と減塩食（ 1 食の食塩 $2.0 \mathrm{~g}$ 以 下）の 2 メニューを提供し，実習期間中は減塩食を 4 日 間継続して摂取した。ただし，実習最終日は，I期の最 終日と同一の献立（常食）を提供・摂取した。減塩食の 調理の際には，八方出しの利用や加工食品の脱塩法，乳 和食や酸味の利用などの手法を実践し，班ごとに同等の 内容となるよう設定した。

\section{(3) リーフレット作成とプレゼンテーション発表}

対象者は，(1)の事前学習課題の内容を活かした減塩に 関するリーフレット作成を行い，食堂の卓上にリーフ レットを設置した。昼食時には食堂利用者に対して，そ の日の提供メニューの減塩のポイントなどのプレゼン テーションを行った。食堂内に減塩や青森県の健康状態 の現状に関するポスターを掲示する等の環境整備を行っ た。作成したリーフレットは, 持ち帰りができるようブー スを設けた。

\section{(4) 分 析}

味覚テストにおける I 〜 III期の真の值と予想值の相関 にはSpearmanの順位相関係数, 差の検定には
Wilcoxon 検定を用いた。食習慣アンケート結果には $\chi^{2}$ 検定を用いた。食事調查は対応のある $t$ 検定を用い前後 比較した。デー夕解析には IBM SPSS Statistics Version 23.0を用いた。

なお, 本研究は, 弘前大学大学院保健学研究科倫理委 員会にて承認を得て実施したものである(整理番号2014013)。

\section{3. 結果}

味覚テストとアンケート分析は，I～III期調査のすべ てのデータが揃った53名を対象とした。食事調査はすべ てのデータが揃った 5 班を対象とした。

\section{（1）味覚テスト}

I 〜 III期の味覚テストにより，塩味に対する味覚の変 化を比較した結果を図 3，4 に示した。I～III期調査の 真の值（日常の塩味に近いと思う濃度），予想值（選ん だ食塩水の予想濃度）は，I 期の真の值と I 期の予想值 のみに有意な相関 $(r=0.445, p<0.01)$ が認められた（図 $3)$ 。また真の值は， I 期に比べて II 期で有意に（ $p<$ 0.05）低いことが認められた（図 4)。

\section{（２）食習慣に関するアンケート}

食習慣アンケートの結果を図 $5 ， 6$ に示した。図 5 に 示すように，日常の食塩摂取に気をつけていると回答し， かつ青森県の食塩摂取量を知っているとする回答者数は, I 期に比べて II 期， III期とも有意に高かった（ $p<0.05 ） 。$ また，青森県の食塩摂取量を知っていると答えた回答者 数は， I 期に比べて II 期， III 期で有意に高く $(p<$ 0.001), 青森県の摂取量を知っていると回答した中で正 確にその摂取量を回答できた者は I 期に比べ，II 期， III 


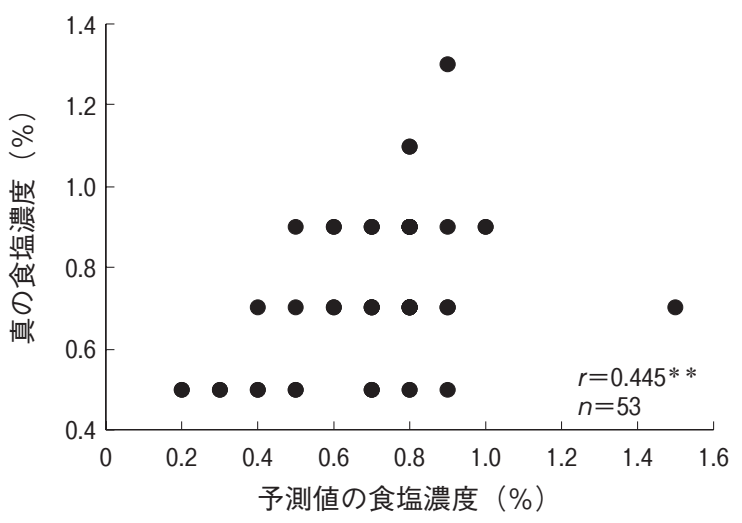

** : $p<0.01$ Spearman の順位相関

図 3 味覚テスト I 期の真の值と予測值の相関

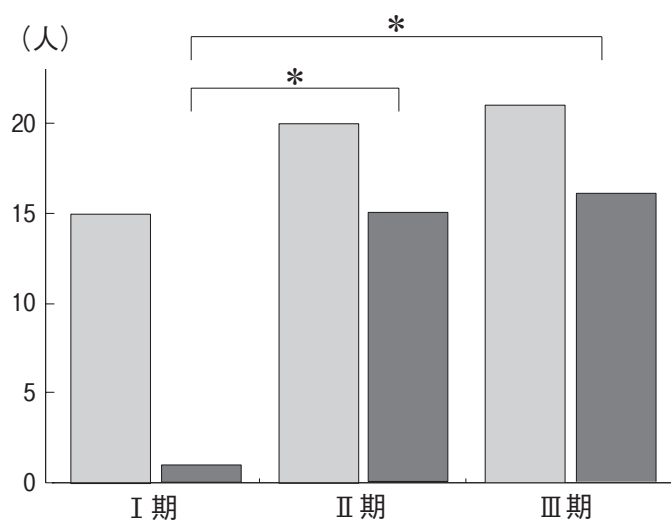

口日常の食塩摂取量に気をつけていると回答した対象者

口日常の食塩摂取量に気をつけている，加青森県の食塩摂 取量を知っていると回答した対象者

$*: p<0.05 \quad \chi^{2}$ 検定

図 5 食塩摂取量に対する意識や知識をもつ対象者

期が有意に多かった $(p<0.001)$ 。

\section{（３）食塩摂取量調査}

食塩濃度の測定方法の妥当性を確認するために行った 予備調査の結果を表 1 に示した。無作為に抽出した 5 食 分それぞれの食事重量, 希釈に用いた水分量など各項目 の変動係数，測定されたナトリウム濃度から算定した食 塩量の変動係数は $5 \%$ 未満であり，測定方法としては妥 当であることが確認された。

次に，提供した 1 食分の料理に含まれる食塩量を予定 献立值と比較した。献立值，実測值，およびその差を表 2 に示した。献立值に比べて実測值の食塩量は有意に高 い值であった $(p<0.01)$ 。

表 3 には，実際に摂取した食事の推定食塩量を示した。 これは，料理に含まれる食塩量の実測值と食事中に使用 した調味料の食塩量, 食器や残菜に含まれる食塩量から 算出したものである。ここでは， 7 班のうち測定できた

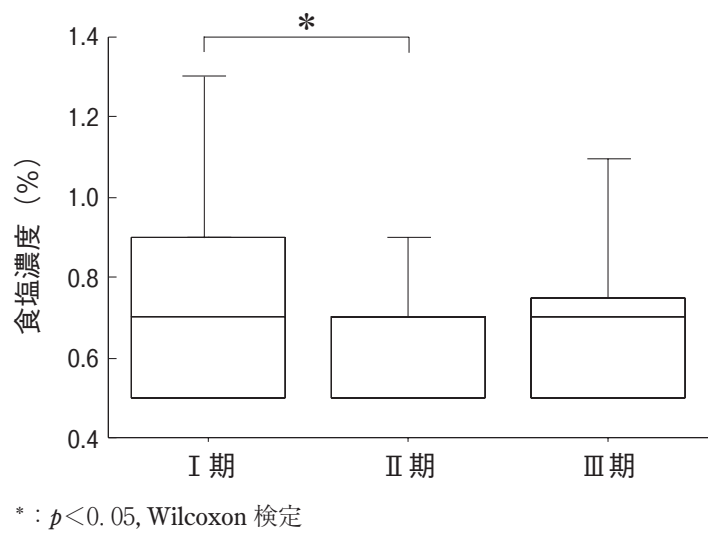

図 $4 \quad \mathrm{I} \sim$ III 期の日常の食塩濃度（真の值）

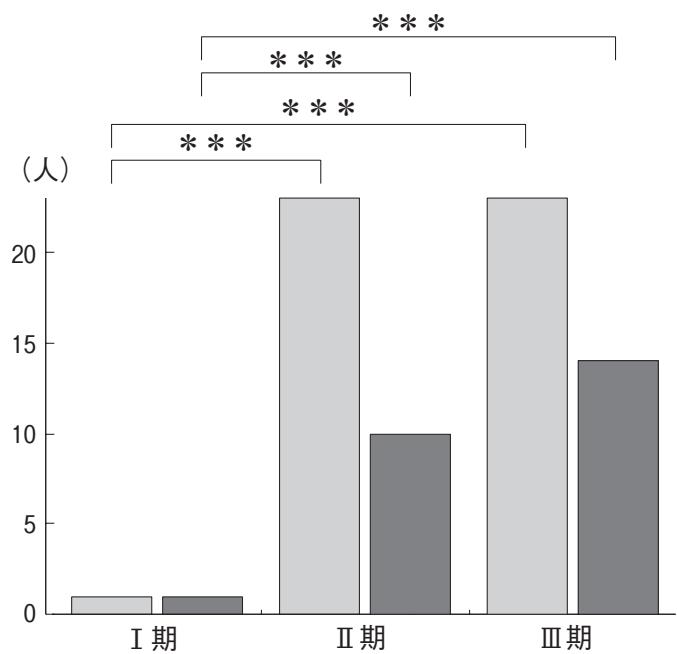

口青森県の食塩摂取量（摂取状況）を知っていると回答した 対象者

口青森県の食塩摂取量を知っていると回答し，かつ正答でき た対象者

*** : $p<0.001, \chi^{2}$ 検定

図 6 青森県の食塩摂取量の把握と正答できた対象者

5 班の結果について示した。使用した調味料中の食塩量 と食事からの推定食塩量が I 期に比べて II 期で有意に低 い（それぞれ $p<0.05 ）$ 值であった。

\section{4. 考察}

本研究は，栄養士課程履修者である対象者に対して減 塩プログラムを実施することによる，減塩に対する意識 の変化や実際の食塩摂取量に与える影響を検証すること を目的としたものである。

味覚テストの結果からは，I期で高い濃度を選んだ対 象者は高い予想值を記入していた（図 3 ) が，II期以降 はその傾向が認められなかった。また，I期の真の值に 対し，II期の真の值が有意に低い值を示した（図 4 )。 II 期より III期では，若干のばらつきが認められたが，有 意な差は認められなかった。このことから減塩学習後の II 期以降は， I 期よりも低い濃度を適度な濃度として選

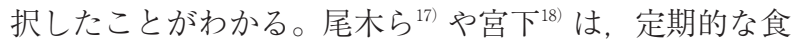




\section{表 21 食分の食事に含まれる食塩量}

\begin{tabular}{|c|c|c|c|c|}
\hline 班 & 献立名\# & 献立值 & 実測值 & 差\# \\
\hline 1 & $\begin{array}{l}\text { イカフライ（付：キャベッ・ミニトマト） } \\
\text { れんこんのきんぴら・小松菜のお浸し }\end{array}$ & 2.2 & 2.1 & -0.1 \\
\hline 2 & $\begin{array}{l}\text { チキンカツ（付：キャベツ・ミニトマト） } \\
\text { ほうれん草のお浸し・ひじき炒め煮 }\end{array}$ & 2.7 & 4. 6 & 1.9 \\
\hline 3 & $\begin{array}{l}\text { メンチカツ（付：キャベツ・ミニトマト） } \\
\text { 小松菜としめじのお浸し・大根のきんぴら }\end{array}$ & 2.6 & 5.2 & 2.6 \\
\hline 4 & $\begin{array}{l}\text { 白身魚のフライ（付：キャベッ・ミニトマト） } \\
\text { ほうれん草のお浸し・切り昆布の煮物 }\end{array}$ & 3.1 & 5.2 & 2.1 \\
\hline 5 & $\begin{array}{l}\text { とりささみカツ（付：キャベツ・ミニトマト） } \\
\text { 白菜のお浸し・きんぴらごぼう }\end{array}$ & 2.3 & 5.6 & 3.3 \\
\hline 6 & $\begin{array}{l}\text { 鮭のフライ（付：キャベツ・ミニトマト） } \\
\text { 白菜とほうれん草のお浸し・ひじき炒め }\end{array}$ & 2.3 & 2.9 & 0.6 \\
\hline 7 & $\begin{array}{l}\text { とんかつ（付：キャベッ・ミニトマト） } \\
\text { 白菜ともやしの接浸し・れんこんきんぴら }\end{array}$ & 2.5 & 4. 1 & 1.6 \\
\hline & 平 均 & $2.5^{* *}$ & 4. 2 & 2.0 \\
\hline & 標準偏差 & 0.31 & 1.30 & 1.32 \\
\hline
\end{tabular}

表 3 実際に摂取した食事の推定食塩量

\begin{tabular}{|c|c|c|c|c|c|c|c|}
\hline \multirow[t]{2}{*}{ 班 } & \multirow{2}{*}{$\begin{array}{l}1 \text { 食分の料理 } \\
\text { に含まれる食 } \\
\text { 塩量の実測値 }\end{array}$} & \multicolumn{2}{|c|}{$\begin{array}{l}\text { 食事中に使用した } \\
\text { 調味料中の食塩量 }\end{array}$} & \multicolumn{2}{|c|}{$\begin{array}{c}\text { 食器や残菜に含まれる } \\
\text { 食塩量 } \\
\end{array}$} & \multicolumn{2}{|c|}{ 推定食塩摂取量 } \\
\hline & & I 期 & II 期 & I 期 & II 期 & I 期 & II 期 \\
\hline 1 & 2.1 & 1.3 & 0.9 & 0.17 & 0.20 & 3.23 & 2.8 \\
\hline 2 & 4.6 & 1.1 & 0.6 & 0.22 & 0.19 & 5. 48 & 5.0 \\
\hline 3 & 5.2 & 1.1 & 0.4 & 0.12 & 0.29 & 6.18 & 5.3 \\
\hline 4 & 5.2 & 1.1 & 1.1 & 0.22 & 0.21 & 6.08 & 6.1 \\
\hline 5 & 5.6 & 1.1 & 0.6 & 0.18 & 0.19 & 6.52 & 6.0 \\
\hline & 平 均 & 1. $1^{*}$ & 0.72 & 0.18 & 0.22 & $5.5^{*}$ & 5. 0 \\
\hline & 標準偏差 & 0.09 & 0.28 & 0.041 & 0.042 & 1. 32 & 1.33 \\
\hline
\end{tabular}

塩濃度の味覚訓練により感受性の高い舌にすることがで きたと報告している。減塩学習前のＩ期に比べ，II期で は 1 週間減塩食を喫食することが一因となって食塩に対 する味覚に変化が生じたと考えられた。またI期では， 講義等で栄養や高血圧等の病態に関して知識を得ていな い時期であり，適度とされる食塩濃度，つまり今回は $0.7 \%$ を基準としたが，その基準に関しても周知されて いなかった。しかしIII期では，さまざまな食事療法を学 ぶ時期であり，適度な食塩濃度や食塩の知識が定着した のではないかと考えられる。その結果，II期と而期の期 間は，特に集中した減塩食契食等の機会はなかったが， 卒業時の正期調査時には，経験により得た塩味の感じ方 と学習で得た適度な食塩濃度の知識の一致がもたらされ たものと推察される。一方, 減塩学習等を履修する中で 生ずる観察者効果が含まれている可能性があることも否
定できない。

食習慣アンケートの結果（図 5 ）から，I 期では日常 の食塩摂取量に気を付けていると回答した対象者が多い が，県民の食塩摂取量の状況や，県民の健康状態につい ては知らない対象者が多かった。II期，III期では県民の 食塩摂取量を正しく把握できている対象者が I 期に比べ て有意に多かった。これらは，アンケートの知識を問う 設問で，意識して覚えようとしたこと，常に減塩に関す る情報に触れる機会が多い環境にいることで，次第に定 着したと考えられる。

食事調查の結果（表 2 ）から，まず献立值と実測值に 差がみられた。原料由来, 調味料由来, 調理上由来の差 かは不明であり，現在調査中である。次に，1食分の料 理に含まれる食塩量の実測值と食事中に使用した調味料 中の食塩量は，I期に比べて II 期での摂取量が有意に低 
い值であったことから，減塩傾向にあり，減塩プログラ ムの影響・効果が示されたものと考える。常松ら ${ }^{19)}$ は, 減塩食実施者は普通食実施者に比べ， $1 \mathrm{~g}$ 程度の減塩を 実行していると報告しているように，減塩食を日常的に 喫食することは塩味の感じ方が鋭敏になる可能性が高い ことを示唆している。本研究では, 昼食のみの提供であっ たため，1 食ではなく継続的な喫食をすすめることがで きればより効果が得られると推察される。また今回の調 査では, II 期調査時に測定機器の不良等により測定不可 能となり欠損值が生じたこと, 繰り返しが困難である給 食管理実習を利用する調査であったことから，減塩傾向 ではあるものの, 確実な効果があったか更なる検討が必 要である。

減塩プログラム (減塩学習) の内容として, 減塩食で はだしの利用 ${ }^{20)}$, 香辛料や酸味の利用, カリウムの利用 や脱塩, 加工食品の塩分の活用といった献立を取り入れ、 通常の調理とは異なった手法や手順を学習した。手法と しては, 通常の調理よりも手がかかるものや, 盛り付け に工夫を要するものなどがあった。学習課題では, 調理 の工夫と塩分を多く含む食品の利用法, 普段の食生活の 中で塩分を減らす工夫などの項目を挙げてレポート提出 をした。常食と同時に減塩食の調理を進めていく中での 工夫などは，栄養士として現場に出た場面の疑似体験も できたようである。実習期間中には，学習課題で得た情 報や，現場での様子をもとに，食堂利用者へ向けた卓上

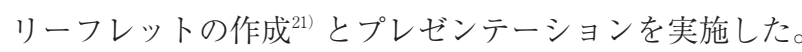
得た知識をいかに効果的に伝えるか, 工夫を凝らした媒 体作成を行っていた。対象者が該当する班の実習期間外 であっても, 食堂利用時には, 県民の健康情報のポスター 掲示を目にする機会, 食塩含有量の記載のある卓上調味 料22)を使用する機会など常に情報にさらされていること， また他の対象者の媒体やプレゼンテーションを参考にす ることなど意識づけにつながったと考えられる。

今回は他の個人単位の調査と異なり,グループ単位で 行った結果であるため, 個人変動は不明である。しかし 総体的には, 減塩の知識や味覚, 効果的な減塩食の手法 について理解し, 継続的な情報提供や減塩食の利用など により，減塩に関する知識や味覚を身につけることがで きると示唆された。

今後の課題として, 対象者にとらわれない継続的で計 画的な取り組みの実施が必要であると考える。学生食堂 は, 栄養士課程履修者以外の在学生や職員も利用し, 身 近な場所であり，情報交換しやすい場所と考え活用・実 施に至った。このような環境において, 継続的な情報提 供を行うことで，学校全体の減塩に対する興味・関心が 高まることを期待した。しかし，対象者以外の利用者が 毎日変わること, 常食と減塩食のセレクトメニューで あったことなども作用し, 広く学校全体のアプローチと しては働きかけや継続の工夫が足りなかった。昼食 1 回 のみを提供する施設であり継続が難しいことも課題とな
るが, 減塩はもちろん, 普段の食生活の見直し, 望まし い食事選択行動が戻ることなく習慣化できるよう組織的 に状況に応じた取り組みを計画的に実施することが望ま しいと考える。食堂利用者に対しても対象者に行った味 覚テストやアンケート調査を行い, 減塩へ興味を向け, 食事を利用して減塩ができることを伝えるなどの取り組 みを行っていきたい。土橋ら ${ }^{23)}$ は, 食塩摂取量を簡便に 評価できる塩分チェックシートの利用による, 滰油や ソースをかける頻度, 昼食での外食・弁当利用などの得 点結果が, 若・ 中年者が高齢者に比べて有意に高かった と報告している。このようなツールを用いて，日常生活 での調味料の使い方についてよく知ること，実際に自身 の食塩摂取量を目の当たりにすることは, 若い世代（学 生）に対する減塩指導として効果的であると考える。今 後の健康の維持増進のため, 若い世代への働きかけが重 要である。

\section{謝 辞}

本研究遂行にあたり，研究にご協力いただきました東 北女子短期大学 2014 年入学の学生の皆様に感謝申し上げ ます。

\section{文献}

1) 菱田明, 佐々木敏監修：日本人の食事摂取基準2015年版, 第一出版, 東京, p. 281 (2014)

2 ）厚生労働省: 平成 27 年国民健康 - 栄養調査結果の概要, http://www.mhlw.go.jp/file/04-Houdouhappyou-10904750Kenkoukyoku-Gantaisakukenkouzoushinka/kekkagaiyou.pdf

3 ) Intersalt Cooperative Research Group: Intersalt: an international study of electrolyte excretion and blood pressure. Results for 24 hour urinary sodium and potassium excretion, BMJ, 297, 319-328 (1988)

4) 佐々木敏：栄養デー夕はこう読む! 疫学研究から読み 解くぶれない食べ方, 女子栄養大出版部, 東京, p. 74-126 (2015)

5 ) 橋本壽夫：食塩摂取量と高血圧の因果関係をめぐって, 栄養学雑誌, 57 ( 5 ), 249-258 (1999)

6 ) 田口徹也, 柳修平, 中村健一：食塩摂取量別ナトリウム 摂取量と尿中排泄量の関連, 民族衛生, 57 ( 3 ), 97-106 (1991)

7 ) 稲垣義明, 斉藤俊弘, 坂口明: 高血圧症と血圧の食塩感 受性，栄養学雑誌，45( 2)，51-58 (1987)

8 ）日本高血圧学会高血圧治療ガイドライン作成委員会：高 血圧治療ガイドライン 2014, 日本高血圧学会, 東京, p. 39 (2014)

9) WHO Guideline: Sodium intake for adults and children. Geneva, World Health Organization (WHO) (2012)

10）厚生労働省：国民健康・栄養調査の現状 平成24年厚生 労働省国民健康 ·栄養調査報告より, 第一出版, 東京, p. 164 (2014)

11）厚生労働省：平成 27 年度都道府県別生命表の概況 都道 府県別にみた平均寿命の推移, http://www.mhlw.go.jp/touk ei/saikin/hw/life/tdfk15/dl/tdfk15-03.pdf

12）中路重之: Dr 中路が語るあおもり県民の健康, 東奥日報社, 青森, p. 10-13 (2013) 
13）厚生労働省：平成27年都道府県別生命表の概況 都道府 県別にみた平均余命, http://www.mhlw.go.jp/toukei/saik in/hw/life/tdfk15/dl/tdfk15-02.pdf

14）農林水産省：第 3 次食育推進基本計画（2016）

15）高橋敦子, 安原安代, 松田康子編：第 6 版調理学実習基 礎から応用，女子栄養大学出版部，東京 (2014)

16）香川達雄：文部科学省科学技術 - 学術審議会 資源調査 分科会報告「五訂増補日本食品標準成分表」による五訂増 補食品成分表2010，凸版印刷，東京（2009）

17）尾木千恵美，加藤信子：女子大生における塩味に対する 味覚感覚, 東海女子短期大学紀要, 20, p. 43-55 (1994)

18）宮下朋子：減塩教育の可能性について一塩分濃度差識別 調查からの検討一, 会津大学短期大学部研究年報, 63, p. 139-146 (2006)

19）常松典子, 上島弘嗣, 奥田奈賀子, 内田克士, 岡山明, 斎藤重幸, 坂田清美, 岡村智教, ソヘル・レザ・チュウドリ, 門脇崇, 喜多義邦, 中川秀昭: 減塩食実施者は通常の食生
活の人に比べ食塩摂取量がどの程度少ないか? INTERMAP日本より〜, 日循予防誌, 39（3），149-156（2004）

20）瀬戸美江，澤田崇子，遠藤金次：味噌汁に対する「だし」 の減塩効果について, 日本調理科学会誌, 36( 3), 219-224 (2003)

21）塚田信, 浦川由美子, 小泉裕子, 田瓜宏二, 杉本裕子： 食育推進のための有効的手法の検討一女子大学学生食堂で の情報媒体による試み一, 鎌倉女子大学学術研究所報, 10 , 25-37 (2010)

22）水津久美子, 稲田絵水, 遠藤亚希子, 久門多賀子, 福泉 真琴: 学生食堂メニューに拈ける栄養成分表示と栄養情報 提供の効果, 山口県立大学生活科学部研究報告, 28, 17-25 (2002)

23）土橋卓也, 増田香織, 鬼木秀幸, 榊美奈子, 荒川仁香, 亀田和花子, 福井浩子: 高血圧患者における簡易食事調査 票「塩分チェックシート」の妥当性についての検討, 血圧, 20(12), 73-77 (2013) 